\title{
Effects of Systemic Inflammatory Parameters on Mortality in Elderly Patients Admitted to Emergency Department with Abdominal Pain
}

\author{
Acil Servise Karın Ağrısı ile Başvuran Yaşı Hastalarda Sistemik Enflamatuvar \\ Parametrelerin Mortalite Üzerine Etkisi \\ (D) Mehmet Veysel Öncül, (D) Seda Dağar, (D) Emine Emektar, (D) Şeref Kerem Çorbacıoğlu, (D) Halit Aytar, (DD Yunsur Çevik \\ University of Health Sciences, Ankara Keçiören Training and Research Hospital, Clinic of Emergency, Ankara, Turkey
}

\begin{abstract}
Introduction: The aim of this study was to evaluate the prognostic value of systemic inflammatory markers, especially neutrophil-lymphocyte ratio (NLR) and platelet-lymphocyte ratio (PLR) in geriatric patients presenting to the emergency department with abdominal pain.

Methods: This retrospective study was conducted in the Emergency Department of University of Health Sciences Ankara Keçiören Training and Research Hospital between 01.08.2016 and 31.12.2016. All patients over 65 years who presented with abdominal pain were included in the study. The demographic data, complete blood count parameters, diagnosis, surgical procedures, [American Society of anesthesiologists (ASA)] scores, length of hospital stay and hospital outcomes were evaluated.

Results: Six hundred and eighty-eight patients were included in the study. Surgery was performed in 77 patients $(12 \%)$. The most frequent diagnosis was bowel obstruction $(n=57,8.3 \%)$. There were statistically significant differences between nonsurvivors ( $n=91$ ) and survivors according to 30-day mortality in terms of age, ASA score, lymphocyte count, NLR and PLR $(p<0.001, p=0.03, p<0.001, p<0.001,40 p>0.001$, respectively). There were also statistically significant differences between non-survivors ( $n=189)$ and survivors according to 365-day mortality in terms of age, surgery type, lymphocyte count, NLR and PLR $(p<0.001, p<0.001, p=0.009, p=0.01, p<0.001$, $p<0.001$ respectively). In the multivariate regression analysis, the clinical feasibility of the laboratory parameters was not significant for both 30 day and 365-day mortality ( $p>0.05)$.
\end{abstract}

Conclusion: According to the results of our study, we believe that NLR and PLR values do not have clinical utility as prognostic markers in determining 30-day and 365-day mortality in geriatric patients presenting with abdominal pain.

Keywords: Abdominal pain, elderly, neutrophil-lymphocyte ratio, platelet-lymphocyte ratio
ÖZ

Amaç: Bu çalıșmada acil servise karın ağrısı ile başvuran geriatrik hastalarda sistemik enflamatuvar parametrelerin, özellikle nötrofil-lenfosit oranı (NLO) ve platelet-lenfosit oranlarının (PLO) prognostik değerlerinin değerlendirilmesi amaçlanmıştır.

Yöntemler: Çalıșma retrospektif bir çalışma olup, 01.08.201631.12.2016 tarihleri arasında bir eğitim ve araștırma hastanesi acil tıp kliniğinde yapıldı. Karın ağrısı şikayeti ile başvuran 65 yaş ve üzeri tüm hastalar çalıșmaya dahil edildi. Hastaların demografik verileri, başvuru anında alınan tam kan sayımı parametreleri beyaz kan hücresi sayımı, tanıları, uygulanan cerrahi yöntemler, American Society of Anaesthesiologists (ASA) skorları, hastanede kalış süreleri ve hastane sonlanımları değerlendirildi.

Bulgular: Çalıșmaya 688 hasta alındı. Hastaların 77’sine (\%12) cerrahi operasyon yapılmıștı. Barsak obstrüksiyonu en sık konulan tanıydı $(n=57, \% 8,3)$. Yaş, ASA skoru, lenfosit, NLO ve PLO arasında ölen ( $n=91)$ ve yașayan hastalar arasında 30 günlük mortaliteye göre istatistiksel olarak anlamlı fark vardı (sırasıyla $p<0,001, p=0,03, p<0,001, p<0,001, p>0,001$ ). Ayrıca yaş, lenfosit, platelet, ASA skoru, NLO ve PLO arasında ölen $(n=189)$ ve yaşayan hastalar arasında 365 günlük mortaliteye göre istatistiksel olarak anlamlı farklılıklar vardı (sırasıyla $p<0,001, p<0,001, p=0,009, p=0,01, p<0,001, p<0,001)$. Çok değișkenli regresyon analizinde ise, incelenen laboratuvar parametrelerinin klinik uygulanabilirliği, hem 30 günlük hem de 365 günlük mortalite için anlamlı bulunmadı ( $p>0,05)$.

Sonuç: Çalışmamızın sonuçlarına göre, karın ağrısı ile başvuran geriatrik hastalarda 30 günlük ve 365 günlük mortaliteyi belirlemede, NLO ve PLO değerlerinin prognostik belirteçler olarak klinik faydası olmadığını düşünüyoruz.

Anahtar Kelimeler: Abdominal ağrı, yașlılık, nötrofil-lenfosit oranı, platelet-lenfosit oranı 


\section{Introduction}

Abdominal pain is one of the first most common causes emergency department admissions for the elderly. In emergency cases, the frequency of abdominal pain in the elderly population was found to be between $3 \%$ and $13 \%$ (1). While two-thirds of elderly patients with abdominal pain are admitted to the hospital, one-fifth of the patients in this group are surgically treated (2). Surgical intervention was found to be twice as high in geriatric patients with abdominal pain compared to younger patients. In addition, in geriatric patients with abdominal pain, the mortality rate is 6 to 8 times higher than other age groups (1). Physical examination findings in patients over 65 years of age who presented to the emergency department with abdominal pain differ from the findings of the young patients. Loss of neural functions in the feeling and assessment of pain, additional diseases, regular or multiple drug use, muscle atrophy are among the causes of this condition (3).

White blood cells (WBC) are regarded as a well-defined inflammatory marker and/or stress indicator. Furthermore, the neutrophil-lymphocyte ratio (NLR) calculated by dividing the absolute neutrophil count by absolute lymphocyte count was introduced as a new indicator for inflammatory response. In terms of mortality, a significant relation is observed between NLR and acute coronary syndrome, non-ST myocardial infarction, ischemic or hemorrhagic strokes, pulmonary embolism, various cancer types. On the other hand, it has been suggested that platelet-lymphocyte ratio (PLR) can be used as a potential indicator for the detection of thrombotic activity or inflammation in various oncological and cardiac diseases $(4,5)$.

There are a limited number of publications in the literature showing the relationship between subtypes of WBC count (especially NLR) and mortality under severe clinical conditions and major surgical interventions. All these parameters can be examined by a complete blood count, which is common, easy and cost-effective.

In our study, we aimed to investigate the prognostic value of these parameters in the abdominal pain of the geriatric age group with high early and late mortality rates.

\section{Methods}

The study was conducted retrospectively between 01.08.2016 and 31.12.2016 following the approval from Ethics Committee of University of Health Sciences Ankara Keçiören Training and Research Hospital (dated 27.07.2016 and numbered 1193). The study was conducted in accordance with World Medical Association Declaration of Helsinki "Ethical Principles for Medical Research Involving Human Subjects", (amended in October 2013). The study was a retrospective study and the consent was not obtained from the patients.

\section{Patient Selection}

The International Classification of Disease-10 codes R10.4 (other and unspecified abdominal pain), K35.9 (acute appendicitis, unspecified), K81.0 (acute cholecystitis), R10.0 (acute abdomen), K56.7 (Ileus, unspecified), K52.8 (other specified non-infective gastroenteritis and colitis) were screened from the hospital automation system (Akgün
Health Information Systems ${ }^{\circledR}$ ) and the study population consisted of patients who met the inclusion criteria.

The demographic data, the complete blood count parameters such as hemoglobin, platelet count, WBC, NLR, Red Cell Distribution Width, PLR on admission, diagnosis, surgical methods, American Society of anesthesiologists (ASA) score, length of hospital stay, comorbidities, clinical outcomes (discharge or death) were obtained from automation system and patient files. In addition to these data, information about the survival status of the patients were obtained from Mortality Notification System of the Institute of Public Health, the Ministry of Health and recorded. Patients with trauma, history of hematologic disease, myocardial infarction within 30-days, liver failure, immunosuppressive status, and patients under the age of 65 and patients with missing data were excluded from the study.

\section{Laboratory Parameters}

Complete blood count is carried out with Abbott Cell-Dyn 3700 (Abbott Laboratories, Illinois, US). NLR was calculated as the ratio of neutrophil count to lymphocyte count, whereas, PLR was calculated as the ratio of platelet count to lymphocyte count.

\section{Statistical Analysis}

Data were analyzed using SPSS for Windows 16 package program. Kolmogorov-Smirnov test was performed to examine whether the distribution of discrete or continuous numerical variables complies with normal distribution. Descriptive statistics were shown as median IQR (25-75) for discrete and continuous numeric variables and as number of observations and percentages (\%) for quantitative data. Categorical variables were assessed with chi-square test and continuous variables were assessed with Mann-Whitney U test. Multivariate Binary Logistic Regression analysis was used to determine adjusted odds ratio (OR) for 30-day and 1-year mortalities. The OR was presented the confidence interval of 95\% [95\% confidence intervals (CI)]. P $<0.05$ was accepted as statistically significant.

\section{Results}

Eight hundred and seventy-six patients were included in this study. After excluding 188 patients who met the exclusion criteria or with missing data, 688 patients were included in the study. Of the included patients, 381 (55.4\%) were female and 307 (44.6\%) were male. The median age was 76 (IQR 70-82) years. The demographic data of the patients are given in Table 1.

Statistical analyzes comparing the demographic and clinical characteristics of non-survivors and survivors according to 30-day mortality are shown in Table 2. There was a statistically significant difference in terms of age, ASA score, lymphocyte count, NLR and PLR. Statistical analyzes comparing the demographic and clinical characteristics of non-survivors and survivors according to 365-day mortality are shown in Table 3. There was a statistically significant difference in terms of age, lymphocyte count, platelet count, ASA score, NLR and PLR.

The multivariate logistic regression analysis was performed with various variables to determine 30-day mortality. Age, NLR, PLR and lymphocyte 
count were included into the established multivariate model that was found acceptable by Hosmer-Lemeshow test, it was noted that it would not be clinically feasible to determine 30-day mortality in consideration of these parameters. It was also considered that the age variable had

\section{Table 1. Demographic and clinical characteristics of patients}

\section{Gender, $\mathbf{n}(\%)$}

Female

$381(55.4)$

Age, years (IQR 25-75\%)

$76(70-82)$

Comorbid diseases, $\mathbf{n}(\%)$

Diabetes mellitus

$198(28.8)$

Hypertension

$168(24.4)$

Coronary artery disease

$204(29.7)$

Congestive heart failure

$81(11.8)$

Chronic renalfailure

$28(4.1)$

Malignancy

$35(5.1)$

\begin{tabular}{l|l} 
Surgically treated patients, $\mathrm{n}(\%)$ & $77(12)$
\end{tabular}

Type of surgery, $\mathbf{n}(\%)$

Midline laparotomy

$35(45)$

Appendectom

$13(17.3)$

Hernia repair

$6(8)$

Cholecystectomy

10 (12)

Perforation repair

8 (11)

Colectomy

$5(6.7)$

\section{ASA score}

ASA-2

ASA-3

ASA-4

ASA-5

\section{$53(7.7)$}

$609(88.5)$

$26(3.8)$

$0(0)$

\section{Diagnosis $\mathbf{n}(\%)$}

Ileus

$57(8.3)$

Acute cholecystitis $39(5.7)$

\begin{tabular}{l|l} 
Acute appendicitis & $19(2.8)$
\end{tabular}

Perforation $\quad 9(1.3)$

\begin{tabular}{l|l} 
Hernia & $4(0.6)$
\end{tabular}

Acute pancreatitis

$45(6.5)$

Mesenteric ischemia

$7(1)$

Other

$508(73.8)$

\section{Laboratory results (IQR\%25-75)}

WBC $(/ \mu \mathrm{L})$

Hemoglobin $(\mathrm{g} / \mathrm{dL})$

$11100(8400-14875)$

Platelet count $\left(\mathrm{x} 10^{3}\right)$

Neutrophil $(/ \mu \mathrm{L})$

Lymphocyte $(/ \mu \mathrm{L})$

NLR

$13.1(11.8-14.3)$

232 (188-295)

8450 (5800-12100)

$1400(900-2100)$

$5.73(3.22-11.0)$

PLR

$161.4(104.95-255.41)$

30-day mortality, $\mathrm{n}(\%)$

$91(13.7)$

365-day mortalit, $\mathrm{n}(\%)$

$189(27.5)$

Length of hospital stay (IQR 25-75\%)

$6(4-10)$

ASA: American Society of Anesthesiology, WBC: white blood cells, NLR: neutrophil to lymphocyte ratio, PLR: platelet to lymphocyte ratio no effect when the width of $\mathrm{Cl}$ was evaluated independently from the significance on the table $(p<0.001,0 R=1.195 \% \mathrm{Cl}: 1.06-1.14)$ (Table 4).

The multivariate logistic regression analysis was performed with various variables to determine 365-day mortality. Age, NLR, PLR, Iymphocyte count, platelet count and hemoglobin level were included into the established multivariate model that was found acceptable by HosmerLemeshow test, it was deemed clinically inapplicable to determine 365day mortality in consideration of these parameters. Similar to 30-day mortality, though the age variable was statistically feasible, it did not have any effect when the width of $\mathrm{Cl}$ was considered independently from the significance on the table $(p<0.001, O R=1.08195 \% \mathrm{Cl}$ : 1.053 1.11) (Table 5).

\section{Discussion}

Regarding the values of routine complete blood count parameters (especially NLR and PLR values) in predicting 30-day and 365-day mortality in elderly patients admitted to emergency department with abdominal pain, we underline two significant results considering the results obtained by our study. First of all, in terms of NLR and PLR values standing as the primary research subjects in our study in accordance with 30-day and 365-day mortality estimates, the NLR and PLR values of nonsurvivors according to 30-day and 365-day mortality were statistically

\section{Table 2. Clinical characteristics of patients according to 30-day} mortality

\begin{tabular}{|l|l|l|l|}
\hline & Non-survivor & Survivor & p \\
\hline Gender, $\mathbf{n}(\%)$ & & & \\
\hline Female & $51(56)$ & $330(55.3)$ & 0.8 \\
\hline Male & $40(44)$ & $267(44.7)$ & $<0.001$ \\
\hline Age, years (IQR 25-75\%) & $82(76-85)$ & $75(69-81)$ & 0.3 \\
\hline $\begin{array}{l}\text { Surgically treated } \\
\text { patients, } \mathrm{n}(\%)\end{array}$ & $13(14.3)$ & $64(10.7)$ & \\
\hline
\end{tabular}

\section{ASA score}

\begin{tabular}{|l|l|l|l|}
\hline ASA 2 & $1(1.1)$ & $52(8.7)$ & \\
\hline ASA 3 & $86(94.5)$ & $523(87.6)$ & 0.03 \\
\hline ASA 4 & $4(4.4)$ & 22 & \\
\hline
\end{tabular}

*Laboratory (IQR\%25-75)

\begin{tabular}{|l|l|l|l}
\hline WBC $(/ \mu \mathrm{L})$ & $\begin{array}{l}11400 \\
(8500-14300)\end{array}$ & $\begin{array}{l}11100 \\
(8500-14300)\end{array}$ & 0.3 \\
\hline Hemoglobin $(\mathrm{g} / \mathrm{dL})$ & $13(11.7-13.9)$ & $13.2(11.8-14.3)$ & 0.1 \\
\hline Platelet count $(\mathrm{x} 103)$ & $\begin{array}{l}242 \\
(187-318)\end{array}$ & $\begin{array}{l}231 \\
(188-292)\end{array}$ & 0.5 \\
\hline Neutrophil $(/ \mu \mathrm{L})$ & 9100 & 8400 & 0.1 \\
\hline Lymphocyte $(/ \mu \mathrm{L})$ & $(5800-14200)$ & $(5800-11700)$ & \\
\hline NLR & $\begin{array}{l}1000 \\
(700-1700)\end{array}$ & $\begin{array}{l}1500 \\
(1000-2200)\end{array}$ & $<0.001$ \\
\hline PLR & $9.2(4.4-16.1)$ & $5.5(3.1-10.1)$ & $<0.001$ \\
\hline & 234.2 & 154.1 & $<0.001$ \\
\hline
\end{tabular}

ASA: American Society of Anesthesiologists, WBC: white blood cells, NLR: neutrophil to lymphocyte ratio, PLR: platelet to lymphocyte ratio *Mann-Whitney U test 
Table 3. Clinical characteristics of patients according to 365-day mortality

\begin{tabular}{|c|c|c|c|}
\hline & Non-survivor & Survivor & $\mathrm{p}$ \\
\hline \multicolumn{4}{|l|}{ Gender, $\mathbf{n}(\%)$} \\
\hline Female & $97(25.5)$ & $284(74.5)$ & \multirow{2}{*}{0.1} \\
\hline Male & $92(30)$ & $215(70)$ & \\
\hline Age, years (IQR 25-75\%) & $80(74-85)$ & $75(69-81)$ & $<0.001$ \\
\hline Surgically treated patients, $\mathrm{n}(\%)$ & $26(33.8)$ & $51(66.2)$ & 0.1 \\
\hline \multicolumn{4}{|l|}{ ASA score } \\
\hline ASA 2 & $6(11.3)$ & $47(88.7)$ & \multirow{3}{*}{0.01} \\
\hline ASA 3 & $178(29.2)$ & $431(70.8)$ & \\
\hline ASA 4 & $5(19.2)$ & $21(80.8)$ & \\
\hline \multicolumn{4}{|l|}{ *Laboratory (IQR\%25-75) } \\
\hline WBC $(/ \mu \mathrm{L})$ & $11200(8500-15000)$ & $11000(8400-14300)$ & 0.3 \\
\hline Hemoglobin (g/dL) & $12.5(11.4-13.9)$ & $13.3(12-14.3)$ & $<0.001$ \\
\hline Platelet count (x103) & $249(188-338)$ & $229(188-282)$ & 0.009 \\
\hline Neutrophil $(/ \mu \mathrm{L})$ & $8900(6200-13250)$ & $8300(5600-11700)$ & 0.081 \\
\hline 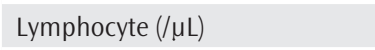 & $1100(725-1675)$ & $1500(1100-2200)$ & $<0.001$ \\
\hline NLR & $7.6(3.7-13.8)$ & $5.4(3.0-10)$ & $<0.001$ \\
\hline PLR & $230(133-330)$ & $148(101-222)$ & $<0.001$ \\
\hline
\end{tabular}

Table 4. Multivariate logistic regression analysis to predict 30-day mortality

\begin{tabular}{|l|l|l|l|}
\hline & Wald & $\mathbf{p}$ & OR $(95 \% \mathrm{CI})$ \\
\hline Age & 30.7 & $<0.001$ & $1.1(1.06-1.14)$ \\
\hline NLR & 7.6 & 0.006 & $1.004(1.001-1.074)$ \\
\hline PLR & 1.1 & 0.2 & $1.001(0.9-1.003)$ \\
\hline Lymphocyte & 1.9 & 0.1 & $1.0(1.0-1.0)$ \\
\hline
\end{tabular}

OR: odds ratio, Cl: confidence intervals, NLR: neutrophil to lymphocyte ratio, PLR: platelet to lymphocyte ratio

\begin{tabular}{l|l|l|l|}
\multirow{2}{*}{$\begin{array}{l}\text { Table 5. Multivariate logistic regression to predict 365-day } \\
\text { mortality }\end{array}$} & Wald & p & OR (95\% CI) \\
\hline & 34.087 & $<0.001$ & $1.081(1.053-1.11)$ \\
\hline Age & 1.562 & 0.2 & $1.018(0.99-1.04)$ \\
\hline NLR & 2.506 & 0.1 & $1.002(1.00-1.004)$ \\
\hline PLR & 0.88 & 0.3 & $1.0(1.00-1.00)$ \\
\hline Lymphocyte & 3.457 & 0.06 & $0.92(0.84-1.004)$ \\
\hline Hemoglobin & 1.427 & 0.2 & $1.00(1.00-1.00)$ \\
\hline Platelet count & & &
\end{tabular}

OR: odds ratio, Cl: confidence intervals, NLR: neutrophil to lymphocyte ratio, PLR: platelet to lymphocyte ratio

significantly higher compared to survivors $(p<0.001)$. Although the OR values for mortality estimation were statistically significant with multivariate logistic regression analysis, we believe that the use of OR in clinical practice is not feasible since the OR values are very close to 1. In addition, the secondary important outcome is that hemoglobin levels were lower in non-survivors according to 365-day mortality compared to survivors, however, platelet counts were higher. However, both statistically and clinically significant results were not achieved in multivariate logistic regression analyzes in terms of determining clinical utility in a similar way. In conclusion, we found that these parameters were not useful in predicting mortality in abdominal pain in the elderly patients.

Physiological changes occur in many systems in the elderly. In addition to these, additional age-related diseases, changes due to previous operations, multidrug use, weakening of the immune system lead to the detection of diseases at a more advanced stage, thus causing an increase in mortality rate $(6,7)$. Abdominal pain in the geriatric age group is one of the most complicated and time-consuming causes of emergency department admissions. Due to obscure findings of physical examinations and low sensitivity of laboratory results in geriatric patients, new indicators are still needed for the diagnosis of acute abdomen in elderly. In the literature, NLR and PLR values, which are regarded as the indicators of diagnosis and predictors of mortality, were higher in certain diseases in all age groups in comparison to the control group (8). Furthermore, this rate was found to be higher in geriatric patient groups (9). Yavuz et al. (10) suggested that preoperative NLR value is a significant data that is easily performed and used for the diagnosis of appendicitis. However, there are numerous studies expressing that these parameters are insufficient as mortality predictor. In the study of Emektar et al. (11) regarding the importance of NLR and PLR values to predict mortality in patients over 65 years of age with femoral fractures, they found that NLR and PLR values were higher in survivors compared to non-survivors. However, the authors noted that the relevant values were not reliable for clinical use when both sensitivity and specifity were considered. In the study conducted by Vaughan-Shaw et al. (12), the relationship between mortality rates and NLR values of patients who underwent abdominal surgery were 
examined, and 30-day and 365-day mortality rates were calculated as $31 \%$ and $50 \%$, respectively. In our study, 30-day and 365-day mortality rates were $13.7 \%$ and $27.5 \%$, respectively. Contrary to Vaughan-Shaw et al. (12), our study population included both patients with and without surgery, therefore this could be one of the reasons of lower mortality rates in our study.

Although our results are not consistent with the current literature, NLR and PLR values were insufficient to predict mortality in patients over 65 years of age with abdominal pain. Therefore, the clinical use of NLR and PLR are poor indicators as a prognostic marker. However, we would encounter these ratios as subtitle in the scoring systems to be developed in accordance with future researches.

\section{Study Limitations}

The retrospective and single-centered structure of this study is the main limitation. The postoperative hematological parameters of the patients were not analyzed. The inflammatory process is a complex process, therefore, other inflammatory parameters were excluded from the scope of this study.

\section{Conclusion}

It is important to identify new risk factors in predicting mortality in geriatric patients with abdominal pain. NLR and PLR are cost-effective, universally accessible and routine parameters that can be easily and rapidly measured without additional cost. According to our study results, we believe that NLR and PLR values are not clinically applicable as a prognostic value in predicting 30-day and 365-day mortality rates in the elderly patients with abdominal pain.

Ethics Committee Approval: The study was conducted retrospectively between 01.08.2016 and 31.12.2016 following the approval from Ethics Committee of University of Health Sciences Ankara Keçiören Training and Research Hospital (dated 27.07.2016 and decision no: 1193).

Informed Consent: The study was a retrospective study and the consent was not obtained from the patients.

Peer-review: Externally peer-reviewed.

Author Contributions: Concept - M.V.Ö.; Design - M.V.Ö., S.D., E.E.; Supervision - E.E., S.K.C., Y.C.; Resources - M.V.Ö., S.D., H.A.; Materials - M.V.Ö., S.D., H.A.; Data Collection and/or Processing - M.V.Ö., H.A.; Analysis and/or Interpretation - E.E., S.K.C., Y.C.; Literature Search
- M.V.Ö., S.D., H.A.; Writing Manuscript - M.V.Ö., E.E.; Critical Review S.K.C., Y.C.

Conflict of Interest: No conflict of interest was declared by the authors. Financial Disclosure: The authors declared that this study received no financial support

\section{References}

1. Birnbaumer DM. The Elder Patient. In: Marx J, Hockberger R, Walls R, (eds). Rosen's Emergency Medicine: Concepts and clinical practice. philadelphia: Mosby Elsevier; 2010: 2348-52.

2. Lewis LM, Banet GA, Blanda M, Hustey FM, Meldon SW, Gerson LW. Etiology and clinical course of abdominal pain in senior patients: A prospective, multicenter study. J Gerontol A Biol Sci Med Sci 2005; 60: 1071-6.

3. Walsh SR, Cook EJ, Goulder F, Justin TA, Keeling NJ. Neutrophil-lymphocyte ratio as a prognostic factor in colorectal cancer. J Surg Oncol 2005; 91: 181-4

4. Huang J, Chen Y, Cai Z, Chen P. Diagnostic value of platelet indexes for pulmonary embolism. Am J Emerg Med 2015; 33: 760-63.

5. Kundi H, Balun A, Cicekcioglu H, Cetin M, Kiziltunc E, Cetin Z, et al. The relation between platelet-to-lymphocyte ratio and Pulmonary Embolism, Severity Index in acute pulmonary embolism. Heart \& Lung: The Journal of Acute and Critical Care 2015; 44: 340-43.

6. Lyon C, Clark D. Diagnostic of acute abdominal pain in older patients. Am Fam Physician 2006; 74: 1537-44.

7. Bugliosi TF, Meloy TD, Vukov LF. Acute abdominal pain in the elderly. Ann Emerg Med 1990; 19: 1383-6.

8. Sun X, Luo L, Zhao X, Ye P, Du R. The neutrophil-to-lymphocyte ratio on admission is a good predictor for all-cause mortality in hypertensive patients over 80 years of age. BMC Cardiovasc Disord 2017; 17: 167.

9. Yan W, Li JZ, He KL. The relationship between neutrophil-to-lymphocyte ratio and major cardiovascular events in elderly patients with chronic heart failure. J Geriatr Cardiol 2017; 14: 780

10. Yavuz E, Ercetin C, Uysal E, Solak S, Biricik A, Yigitbas H. Diagnostic value of neutrophil/lymphocyte ratio in geriatric cases with appendicitis. Turk Geriatri Derg 2014; 17 345-9.

11. Emektar E, Corbacioglu, SK, Dagar S, Uzunosmanoglu H, Safak T, Cevik Y. Prognostic value of the neutrophil-lymphocyte and platelet-hip fracture, neutrophil-lymphocyte ratio, platelet-lymphocyte ratio, one-year mortality lymphocyte ratios in predicting one-year mortality in patients with hip fractures and aged over 60 years. Eurasian J Med 2017; 16: 165-70.

12. Vaughan-Shaw PG, Rees JR, King AT. Neutrophil lymphocyte ratio in outcome prediction after emergency abdominal surgery in the elderly. Int J Surg 2012 10: $157-62$. 